\title{
The Communication Patterns of Internal Medicine and Family Practice Physicians
}

\author{
Michael Paasche-Orlow, MD, MPH, and Debra Roter, DrPH
}

Background: Although differences between Internal Medicine (IM) and Family Practice (FP) physicians have been examined in terms of care outcomes and cost, there have been few studies of specialty differences in physician-patient communication.

Methods: In 1995, 277 clinical encounters with 29 full-time, community-based FP physicians and 287 clinical encounters with 30 full-time, community based IM physicians were audiotaped. Communication was evaluated with the Roter Interaction Analysis System to reflect data gathering, patient education and counseling, rapport building, partnership building, verbal dominance, and patient-centeredness.

Patient satisfaction was measured with an exit questionnaire.

Results: IM clinicians ask more biomedical questions $(P=.02)$. FP clinicians engage in more psychosocial discussion $(P=.02)$ and tend to engage in more emotionally supportive exchanges such as empathy and reassurance $(P=.06)$. Significant interaction effects show differential treatment of patient subgroups by specialty; FP physicians were more verbally dominant with female patients $(P<.01)$ and more patient-centered in their communication style with minority patients $(P=.03)$. Although patient satisfaction was similar for IM and FP, satisfaction was more closely linked to measures of rapport and patient-centeredness for patients of FP physicians than for patients of internists.

Conclusions: The current work adds insight into FP and IM differences in both physician-patient communication and predictors of patient satisfaction. (J Am Board Fam Pract 2003;16:485-93.)

Multiple reports have detailed differences in the process and cost of care provided by Internal Medicine (IM) and Family Practice (FP) clinicians. ${ }^{1-24}$ The origin of these specialty differences may stem in part from curricular priorities exhibited in residency education. FP residency programs devote 3 times as many formal training hours to psychosocial issues and interviewing skills as IM residency programs. $^{25}$

The communication patterns of IM and FP have been compared in 2 reports both describing a single set of resident physicians at the University of California Davis Medical Center. Bertakis et $\mathrm{al}^{26,27}$ used the Davis Observation Code (DOC) to analyze initial and subsequent clinical encounters for patients randomly assigned to the FP or IM resident physician clinics. Both reports conclude that

Submitted, revised, 18 March 2003.

From the Departments of Medicine (MP-O) and Health Policy and Management (DR), Johns Hopkins University, Baltimore, Maryland. Address correspondence to Dr. Michael Paasche-Orlow, Section of General Internal Medicine, Department of Medicine, Boston University School of Medicine, 91 East Concord Street, Suite 200, Boston, MA 02118 (e-mail: mpo@bu.org).

MP-O was supported by grant T32-HL07180 from the National Heart, Lung, and Blood Institute. the IM residents spent more time collecting information and discussing treatments and that the FP residents focused more on emotional counseling than did the IM residents. Physician specialty did not predict patients' self-reported health status or satisfaction.

Based on these observations ${ }^{26,27}$ and our own prior work, hypotheses were developed regarding the communication practices of IM and FP clinicians in relation to the 4 functions of the medical interview: (1) data gathering, (2) patient education and counseling, (3) rapport building, and (4) partnership building. ${ }^{28,29}$

We hypothesized that: (1) IM physicians would conduct visits with more data gathering, (2) FP physicians would undertake more patient education and counseling, (3) FP physicians would exhibit more rapport building, and (4) FP clinicians would exhibit more partnership building. In addition, we hypothesized that: (5) IM clinicians would be more verbally dominant in their patient exchanges and (6) FP clinicians would score higher on a summary measure of patient-centeredness. Finally, because satisfaction measures are typically correlated with patient-centered communication elements, we hypothesized that patient satisfaction would be higher for FP physicians. 


\begin{tabular}{|c|c|c|c|}
\hline Characteristic & $\begin{array}{c}\mathrm{IM} \\
\mathrm{n}=30(\mathrm{SD})\end{array}$ & $\begin{array}{c}\mathrm{FP} \\
\mathrm{n}=29(\mathrm{SD})\end{array}$ & $P$ \\
\hline Mean age & $42.9(8.9)$ & $38.1(4.1)$ & $.01 \quad\left(t_{57}=2.66\right)$ \\
\hline Years in practice & $12.9(9.1)$ & $8.5(3.2)$ & $.02 \quad\left(\mathrm{t}_{57}=2.45\right)$ \\
\hline Sex: male/female & $27 / 3$ & $26 / 3$ & $.97 \quad\left(\chi^{2}(1)<.01\right)$ \\
\hline Ethnicity: white/minority & $25 / 5$ & $25 / 4$ & $.79\left(\chi^{2}(1)=.07\right)$ \\
\hline \multicolumn{4}{|l|}{ Practice Setting } \\
\hline Solo & $5(17 \%)$ & $11(37 \%)$ & \\
\hline Small group & $11(37 \%)$ & $6(21 \%)$ & \\
\hline HMO & $14(46 \%)$ & $12(41 \%)$ & $.15\left(\chi^{2}(2)=3.86\right)$ \\
\hline Board certification & $28 / 30$ & $29 / 29$ & $.85\left(\chi^{2}(1)=.03\right)$ \\
\hline
\end{tabular}

\section{Subjects and Methods}

To evaluate these hypotheses, we conducted a secondary data analysis of 564 audiotaped patient encounters conducted in 1995 with $30 \mathrm{IM}$ and $29 \mathrm{FP}$ community-based clinicians. Audiotapes of these encounters were collected as part of a randomized trial of communication skills training. ${ }^{30}$

\section{Physicians}

Full-time primary care physicians in the greater Baltimore metropolitan area were recruited from local medical society mailing lists to participate in a study to evaluate a continuing medical education (CME) program. Eighty-eight physicians (16\% of those contacted) agreed to all aspects of the study and 69 of these physicians fully participated. Ten of these physicians were not board-eligible and were excluded from analysis. Of the remaining 59 physicians, 29 were identified as Family Physicians and 30 were identified as Internists.

Informed consent was obtained at enrollment of physicians in the study. Physicians were located in solo, small group, and HMO settings. Female physicians accounted for $10 \%$ of the sample. Physicians contributed an average of 9.6 (range, 6 to 11) audiotapes. IM physicians were older with a greater number of years in practice. Physician characteristics are summarized in Table 1.

\section{Patients}

Patients were recruited immediately preceding their medical appointments; informed consent was obtained at the time of recruitment. Seventy-two percent of patients who were approached gave their consent. Patients completed short pre- and postvisit health-status questionnaires that included self-ratings of physical and emotional health. ${ }^{31}$ In addition, at the conclusion of their office visits, patients completed a 16-item satisfaction questionnaire with adequate internal reliability $(\alpha=0.87){ }^{29}$

Differences between the IM and FP patients were determined for patient age, income, and work status; the IM patients were older, less wealthy, and reported lower levels of employment. Patient characteristics are summarized in Table 2.

\section{Study Variables}

Audiotapes were analyzed using the Roter Interaction Analysis System (RIAS), a widely used quantitative approach to audiotape coding. ${ }^{32}$ The RIAS catalogues each complete thought expressed by the patient or physician into mutually exclusive and exhaustive categories. The categories of the RIAS taxonomy correspond to the biomedical and socioemotional functions of the visit. ${ }^{29,33}$

The RIAS codes were divided into composite summary measures to evaluate our specified hypotheses. The first 4 composites regarding data gathering, patient education and counseling, rapport building, and partnership building are the simple sum of their constituent code frequencies, as depicted in Table 3.

Verbal dominance was defined as the sum of all physician statements divided by the sum of all patient statements, as has previously been described. ${ }^{34}$ Patient-centeredness was defined as the sum of all codes relating to socioemotional handling and the psychosocial agenda of the patient divided by the sum of all codes related to furthering the biomedical agenda. ${ }^{35}$ The numerator for this equation includes all patient-centered RIAS codes: all physician and patient comments and questions relating to psychosocial and lifestyle-related topics, all physician and patient statements of partnership building, social talk, positive talk, and statements that respond to emotions. The denominator for 
Table 2. Patient Characteristics

\begin{tabular}{|c|c|c|c|}
\hline Characteristic & $\begin{array}{c}\mathrm{IM} \\
\mathrm{n}=287(\%)\end{array}$ & $\begin{aligned} \mathrm{FP} \\
\mathrm{n}=277(\%)\end{aligned}$ & $P$ \\
\hline Mean Age & 52.17 & 46.43 & $<.01(\mathrm{t}=3.84)$ \\
\hline Female & $182(64)$ & $171(62)$ & $.64\left(\chi^{2}(1)=0.22\right)$ \\
\hline $\begin{array}{l}\text { Ethnicity } \\
\text { White } \\
\text { Minority }\end{array}$ & $\begin{array}{r}242(84) \\
42(15)\end{array}$ & $\begin{array}{r}218(79) \\
57(21)\end{array}$ & $.07\left(\chi^{2}(1)=3.38\right)$ \\
\hline $\begin{array}{c}\text { Income in } \$ \\
0 \\
<10,000 \\
<20,000 \\
<30,000 \\
<40,000 \\
>40,000\end{array}$ & $\begin{array}{l}27(9) \\
40(14) \\
50(17) \\
54(19) \\
44(15) \\
71(25)\end{array}$ & $\begin{array}{l}10(4) \\
44(16) \\
46(17) \\
45(16) \\
36(13) \\
96(35)\end{array}$ & $.02\left(\chi^{2}(5)=13.39\right)$ \\
\hline $\begin{array}{l}\text { Education } \\
<\text { High school } \\
\text { High school graduate } \\
<4 \text { years' college } \\
\text { College graduate } \\
\text { Postgraduate }\end{array}$ & $\begin{array}{r}74(26) \\
110(38) \\
39(14) \\
31(11) \\
32(11)\end{array}$ & $\begin{array}{l}65(23) \\
87(31) \\
44(16) \\
36(13) \\
45(16)\end{array}$ & $.2\left(\chi^{2}(4)=5.99\right)$ \\
\hline $\begin{array}{l}\text { Work status } \\
\text { Full time } \\
\text { Part time } \\
\text { Unemployed } \\
\text { Retired } \\
\text { Disabled } \\
\text { Other }\end{array}$ & $\begin{aligned} & 131(46) \\
& 17(6) \\
& 42(15) \\
& 84(29) \\
& 8(3) \\
& 4(1)\end{aligned}$ & $\begin{array}{l}13(5) \\
31(11) \\
55(20) \\
7(3) \\
14(5)\end{array}$ & $.01\left(\chi^{2}(5)=16.07\right)$ \\
\hline $\begin{array}{l}\text { Visit history } \\
\text { Prior visits } \\
\text { No prior visits }\end{array}$ & $\begin{array}{r}229(80) \\
58(20)\end{array}$ & $\begin{array}{r}205(74) \\
72(26)\end{array}$ & $.10\left(\chi^{2}(1)=2.66\right)$ \\
\hline $\begin{array}{l}\text { Self-rated physical healtl } \\
\text { Excellent } \\
\text { Very good } \\
\text { Good } \\
\text { Fair }\end{array}$ & $\begin{array}{r}134(47) \\
69(24) \\
68(24) \\
13(5)\end{array}$ & $\begin{array}{c}144(52) \\
67(24) \\
49(18) \\
16(6)\end{array}$ & $.30\left(\chi^{2}(3)=3.67\right)$ \\
\hline $\begin{array}{l}\text { Physician-rated physical } \\
\text { Excellent } \\
\text { Good } \\
\text { Fair } \\
\text { Poor } \\
\text { GHQ Score* }\end{array}$ & $\begin{array}{c}43(15) \\
167(59) \\
64(23) \\
8(3) \\
5.32(0.33)\end{array}$ & $\begin{array}{c}49(18) \\
150(55) \\
71(26) \\
5(2) \\
5.04(0.32)\end{array}$ & $\begin{array}{c}.52\left(\chi^{2}(3)=2.27\right) \\
P=.54\end{array}$ \\
\hline
\end{tabular}

* Mean (SE).

this equation includes all doctor-centered RIAS codes: all physician and patient biomedical question asking and information giving and physician counseling on biomedical topics. As such, a value greater than 1 denotes a more psychosocially oriented encounter and a value less than 1 denotes a more biomedically oriented encounter.

The audiotapes were coded by 3 persons trained in the RIAS system. Reliability of coding was assessed by double-coding a $10 \%$ random sample of audiotapes drawn throughout the coding period. The average intercoder reliability was .73 and ranged between .62 and .98 for individual categories. In addition to the discrete category coding, coders also rated the emotional tone of the visits on a 6-point Likert scale for 5 affective domains: anger, dominance, interest, responsiveness, and friendliness. Coder agreement on the affect ratings within 1 point ranged from .63 to .84 .

\section{Data Analysis}

The communication patterns of IM and FP physicians were compared by contrasting the mean counts of their behaviors within the 4 functions of the visit (data gathering, patient education and counseling, rapport building, and partnership building), and in verbal dominance and a summary score of patient-centeredness. These same analyses were conducted with encounter duration as a single control variable.

Next, we performed multivariate analyses for data gathering, patient education and counseling, 
Table 3. The Roter Interactional Analysis System (RIAS): Frequency of Four Code Groupings According to Physician Specialty*

\begin{tabular}{|c|c|c|c|c|c|c|c|c|c|}
\hline \multirow[b]{2}{*}{ Communication Behavior } & \multicolumn{3}{|c|}{ Unadjusted } & \multicolumn{3}{|c|}{$\begin{array}{l}\text { Controlled for } \\
\text { Encounter } \\
\text { Duration Only }\end{array}$} & \multicolumn{3}{|c|}{ Expanded Model $^{\dagger}$} \\
\hline & $\mathrm{IM}$ & FP & $P$ & IM & FP & $P$ & $\mathrm{IM}$ & FP & $P$ \\
\hline $\begin{array}{l}\text { I. Data gathering } \\
\text { a. Closed-ended biomedical questions } \\
\text { b. Open-ended biomedical questions } \\
\text { c. Closed-ended psychosocial questions } \\
\text { d. Open-ended psychosocial questions } \\
\text { e. Bids for clarification } \\
\text { Total count }\end{array}$ & $\begin{array}{r}23.1 \\
2.9 \\
8.7 \\
1.6 \\
1.2 \\
37.4\end{array}$ & $\begin{array}{r}16.5 \\
3.0 \\
6.8 \\
1.5 \\
0.3 \\
28.2\end{array}$ & $\begin{array}{l}.02^{\ddagger} \\
.24 \\
.11 \\
.72 \\
.05^{\ddagger} \\
.02^{\ddagger}\end{array}$ & $\begin{array}{r}21.4 \\
2.9 \\
8.9 \\
1.5 \\
1.2 \\
36.0\end{array}$ & $\begin{array}{r}18.6 \\
3.0 \\
6.8 \\
1.6 \\
0.3 \\
30.1\end{array}$ & $\begin{array}{l}.05^{\ddagger} \\
.74 \\
.04^{\ddagger} \\
.54 \\
.06 \\
.02^{\ddagger}\end{array}$ & $\begin{array}{r}22.2 \\
2.3 \\
8.0 \\
2.3 \\
1.0 \\
35.8\end{array}$ & $\begin{array}{r}18.4 \\
2.4 \\
6.2 \\
2.4 \\
0.1 \\
29.6\end{array}$ & $\begin{array}{l}.01^{\ddagger} \\
.64 \\
.09 \\
.79 \\
.14 \\
.02^{\ddagger}\end{array}$ \\
\hline $\begin{array}{l}\text { II. Patient education and counseling } \\
\text { a. Provides biomedical information } \\
\text { b. Provides psychosocial information } \\
\text { c. Counsels biomedical } \\
\text { d. Counsels psychosocial } \\
\text { Total count }\end{array}$ & $\begin{array}{r}32.0 \\
3.9 \\
14.2 \\
7.2 \\
57.5\end{array}$ & $\begin{array}{r}37.6 \\
7.6 \\
13.8 \\
8.0 \\
67.4\end{array}$ & $\begin{array}{l}.19 \\
.02^{\ddagger} \\
.78 \\
.56 \\
.18\end{array}$ & $\begin{array}{r}32.8 \\
3.9 \\
14.1 \\
7.4 \\
59.7\end{array}$ & $\begin{array}{r}37.3 \\
7.8 \\
13.9 \\
8.3 \\
66.4\end{array}$ & $\begin{array}{l}.04^{\ddagger} \\
.02^{\ddagger} \\
.87 \\
.39 \\
.08\end{array}$ & $\begin{array}{r}31.7 \\
5.6 \\
14.7 \\
5.2 \\
57.3\end{array}$ & $\begin{array}{r}34.9 \\
8.1 \\
13.3 \\
5.5 \\
61.8\end{array}$ & $\begin{array}{l}.22 \\
.02^{\ddagger} \\
.23 \\
.81 \\
.25\end{array}$ \\
\hline $\begin{array}{l}\text { III. Rapport building } \\
\text { a. Personal remark } \\
\text { b. Laughter } \\
\text { c. Approval } \\
\text { d. Empathy } \\
\text { e. Concern } \\
\text { f. Reassure } \\
\text { g. Legitimate } \\
\text { Total count }\end{array}$ & $\begin{array}{r}7.8 \\
2.8 \\
3.8 \\
0.3 \\
2.1 \\
3.4 \\
0.6 \\
20.9\end{array}$ & $\begin{array}{r}8.6 \\
3.5 \\
4.7 \\
0.5 \\
2.3 \\
3.9 \\
0.7 \\
24.3\end{array}$ & $\begin{array}{l}.69 \\
.30 \\
.26 \\
.07 \\
.49 \\
.38 \\
.46 \\
.34\end{array}$ & $\begin{array}{r}8.0 \\
2.9 \\
1.2 \\
0.3 \\
2.1 \\
3.4 \\
0.7 \\
18.6\end{array}$ & $\begin{array}{r}8.3 \\
3.4 \\
1.6 \\
0.5 \\
2.4 \\
4.0 \\
0.8 \\
21.0\end{array}$ & $\begin{array}{l}.80 \\
.30 \\
.46 \\
.06 \\
.30 \\
.13 \\
.30 \\
.26\end{array}$ & $\begin{array}{r}9.9 \\
3.7 \\
4.7 \\
0.4 \\
2.9 \\
4.7 \\
0.9 \\
27.6\end{array}$ & $\begin{array}{r}10.6 \\
5.1 \\
5.0 \\
0.6 \\
3.1 \\
5.6 \\
1.0 \\
30.9\end{array}$ & $\begin{array}{l}.31 \\
.03^{\ddagger} \\
.13 \\
.06 \\
.35 \\
.06 \\
.54 \\
.14\end{array}$ \\
\hline $\begin{array}{l}\text { IV. Partnership building } \\
\text { a. Paraphrase } \\
\text { b. Partnering } \\
\text { c. Asks for opinion } \\
\text { d. Asks for understanding } \\
\text { e. Asks for reassurance } \\
\text { Total count }\end{array}$ & $\begin{array}{l}4.3 \\
0.1 \\
0.5 \\
3.3 \\
0.0 \\
8.2\end{array}$ & $\begin{array}{l}3.4 \\
0.1 \\
0.3 \\
3.0 \\
0.0 \\
6.8\end{array}$ & $\begin{array}{l}.16 \\
.22 \\
.24 \\
.58 \\
.62 \\
.21\end{array}$ & $\begin{array}{l}3.8 \\
0.1 \\
0.5 \\
3.1 \\
0.0 \\
7.6\end{array}$ & $\begin{array}{l}3.9 \\
0.1 \\
0.3 \\
3.1 \\
0.0 \\
7.6\end{array}$ & $\begin{array}{l}.31 \\
.20 \\
.18 \\
.96 \\
.69 \\
.97\end{array}$ & $\begin{array}{l}4.9 \\
0.0 \\
0.5 \\
3.3 \\
0.0 \\
8.5\end{array}$ & $\begin{array}{l}4.6 \\
0.1 \\
0.4 \\
3.0 \\
0.1 \\
8.3\end{array}$ & $\begin{array}{l}.47 \\
.46 \\
.52 \\
.31 \\
.90 \\
.88\end{array}$ \\
\hline
\end{tabular}

IM, internal medicine; FP, family practice.

* Frequency analysis conducted using two-tailed significance testing and generalized estimation equations to control for variable number of office visits per physician.

${ }^{\dagger}$ Controlled for duration of encounter, experimental group, generalized health questionnaire (GHQ) score, being an established patient, physician age, patient income, patient ethnicity, and patient age.

${ }^{\ddagger} P<.05$.

rapport building, partnership building, verbal dominance, and patient-centeredness. As physicians contributed a varied number of patient encounters, general estimating equation (GEE) techniques for panel data were used to cluster data by physician. ${ }^{36}$ Patient and physician sociodemographic characteristics were entered for adjustment to take into account underlying differences in these characteristics. Control variables, including physician age, experimental group status, years in practice, patient age, patient income, patient sex, patient ethnicity, history of prior visits, Generalized Health Questionnaire (GHQ) score, and duration of encounter were specified a priori and additional characteristics and interactions were explored to improve model fit.

Statistical analyses were conducted using STATA version 7.0 (Stata Corporation, College
Station, TX). The authors had full access to all the data in the study, have no financial or personal conflict of interest, and accept responsibility for the integrity of the data and analysis.

\section{Results}

\section{RIAS Communication Analysis}

Table 3 exhibits the frequency of interaction categories by physician specialty. Interaction categories that showed specialty differences in bivariate analysis included higher levels of closed-ended biomedical questions and bids for clarification for Internists, and higher levels of psychosocial information giving for family physicians. A trend suggesting higher levels of empathy for family practitioners was also evident $(P=.07)$. When adjusted for encounter duration, higher levels of closed-ended psychosocial questions by internists were also evident. 
Table 4. Determinants of Verbal Dominance and Patient-Centeredness

\begin{tabular}{|c|c|c|c|c|}
\hline Dependent Variable & Equation & Specialty & Ratio & Point Estimate of Difference (95\% CI) \\
\hline \multirow[t]{8}{*}{ Verbal dominance } & Univariate & IM & 1.1 & $0.16(0.03,0.28)^{*}$ \\
\hline & 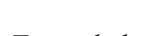 & $\mathrm{FP}$ & 1.3 & \\
\hline & Expanded $n$ & stratified by patient & & \\
\hline & & $\begin{array}{l}\text { Male patients } \\
\text { IM }\end{array}$ & 1.1 & $0.05(-0.17,0.269)$ \\
\hline & & FP & 1.2 & \\
\hline & & Female patients & & \\
\hline & & IM & 1.2 & $0.22(0.05,0.39)^{*}$ \\
\hline & & $\mathrm{FP}$ & 1.4 & \\
\hline \multirow[t]{8}{*}{ Patient-centeredness } & Univariate & IM & 1.1 & $0.05(-0.14,0.23)$ \\
\hline & & FP & 1.1 & \\
\hline & Expanded $\mathrm{r}$ & $\begin{array}{l}\text { stratified by patient } \\
\text { White patients }\end{array}$ & & \\
\hline & & IM & 1.2 & $0.04(-0.18,0.26)$ \\
\hline & & FP & 1.2 & \\
\hline & & African American 1 & & \\
\hline & & IM & 1.1 & $0.32(0.01,0.62)^{*}$ \\
\hline & & $\mathrm{FP}$ & 1.4 & \\
\hline
\end{tabular}

Verbal dominance is the ratio of all physician's talk divided by all patient's talk. Patient-centeredness is the ratio of physician's psychosocial codes divided by the physician's biomedical task codes.

$* P<.05$

${ }^{\dagger}$ Controlled for experimental group, physician age, patient age, patient income, and patient ethnicity.

${ }^{\ddagger}$ Controlled for experimental group, physician age, patient age, patient income, and patient gender.

Inclusion of additional potential confounding variables related to the original study intervention (ie, experimental group membership and the patient's GHQ score) as well as other patient and physician characteristics (ie, being an established patient, physician age, patient income, patient ethnicity, and patient age) in an expanded model, showed persistent specialty differences favoring internists in higher levels of data gathering and family practitioners in higher levels of psychosocial information giving. In addition, family practitioners showed higher levels of laughter and trends indicating higher levels of empathy and reassurance $(P=.06$, respectively). No differences were evident in the partnership building categories.

\section{Verbal Dominance and Patient-Centeredness}

As seen in Table 4, FP physicians exhibited significantly more verbal dominance than IM physicians. After controlling for potential covariates, patient gender emerged as a significant interaction variable; between-specialty differences in verbal dominance were evident only with female patients. Similarly, after controlling for covariates, patient ethnicity emerged as a significant interaction variable such that between-specialty differences in patient-centeredness were evident only for African American patients.

\section{Global Assessment}

Global affect ratings by coders for physicians revealed a higher rating of friendliness for FP (IM = $4.0, \mathrm{FP}=4.3 ; P=.05$ ) but no differences in other affective ratings. No differences were found in the raters' global affect ratings of patients.

\section{Patient Satisfaction}

No specialty distinctions were evident in patient satisfaction ratings $(P=.91)$. For both IM and FP, satisfaction was correlated with rapport building and psychosocial communication categories. However, this association was substantially stronger for patients of FP than for IM (Table 5); the correlations between patient satisfaction and both psychosocial and rapport building communication were more than doubled in magnitude for family physicians than internists in each case. We also found substantially higher correlations between psychosocial talk and satisfaction for female compared with male patients ( 0.20 vs 0.03$)$, regardless of physician specialty. For the summary score of patient-centeredness, patient satisfaction showed a significant correlation only for patients of family practitioners.

\section{Discussion}

Consistent with previous studies with medical residents, ${ }^{26,27}$ community-based IM physicians en- 
Table 5. Correlation between Patient-Centeredness and Patient Satisfaction*

\begin{tabular}{llc}
\hline & \multicolumn{2}{c}{ Patient Satisfaction } \\
\cline { 2 - 3 } & Internists & Family Practice \\
\hline Rapport building communication & $0.13^{\dagger}$ & $0.28^{\ddagger}$ \\
Psychosocial communication & $0.14^{\dagger}$ & $0.29^{\ddagger}$ \\
Biomedical communication & 0.06 & 0.06 \\
Patient-centeredness & 0.04 & $0.25^{\ddagger}$ \\
\hline
\end{tabular}

Patient-centeredness $=($ physician's psychosocial codes $) /($ physician's biomedical codes)

* Pairwise correlation matrix with Bonferroni adjustment

${ }^{\dagger} P<.05$

${ }^{\ddagger} P<.001$

gage in more data gathering with their patients, and FP clinicians provide more psychosocial information and tend to engage in more emotionally supportive exchanges such as empathy and reassurance with their patients. We also found some evidence that FP clinicians may relate to particular subgroups of patients in a different manner than their IM colleagues; FP physicians were more verbally dominant with their female patients and more patient-centered with African American patients than were Internists.

Further exploration of our data showed that the increased verbal dominance exhibited by FP physicians with their female patients was a result of a higher level of physician psychosocial talk. In light of the substantially higher correlation between psychosocial talk and satisfaction for female compared with male patients, FP clinicians may be responding to patient cues that encourage this type of communication.

Evaluation of the finding of increased patientcenteredness directed toward African American patients by FP clinicians reveals especially high levels of rapport building communication. This may reflect an attempt by FP clinicians to ameliorate the more negative experiences of African American patients with the medical system compared with their white counterparts. For instance, the Commonwealth Survey found that $15 \%$ of African American patients believed that they would receive better health care if they were of a different race or ethnicity; the survey also found that African American patients were almost twice as likely as their white counterparts ( $16 \%$ vs. $9 \%)$ to report treatment with disrespect during a recent health care visit. ${ }^{37}$

Although a statistical trend existed for an increased number of empathic and reassurance state- ments made by FP physicians in this study, the actual mean number of empathic statements made per encounter was very small $(0.5$ and 0.3 for FP and $\mathrm{IM}$, respectively; $P=.06)$. It is possible that statements of empathy represented critical incidents of affective bonding, and even modest differences in the use of this low incidence code represent clinically relevant distinctions in communication. Although the frequency of reassurance statements was also higher for FP than IM (5.6 and 4.7, respectively, $P=.06$ ) the difference was also quite small. It is notable that the frequency of these behaviors and several other powerful tools of rapport and partnership building was low for both IM and FP physicians.

Patient satisfaction was similar for IM and FP encounters. However, the pattern of association between patient satisfaction and communication categories revealed an unanticipated specialty difference. The satisfaction of FP patients was more closely linked to rapport building, psychosocial exchange, and patient-centeredness than they were for patients of IM clinicians. It is possible that patients who select FP clinicians may do so because they believe and expect FP to be more psychosocial and emotionally supportive and less likely to exhibit a biomedically intensive communication style than Internists. In response, the physicians may indeed exhibit those qualities of exchange that are expected. ${ }^{38}$ In this light, some measure of the difference between the 2 specialties may stem from cultural differences both in specialty training and in the background and expectations of the patients who frequent these clinicians.

This study has certain limitations. First, as a secondary data analysis, this study was not designed to evaluate variability by specialty, but to assess a communication skills training intervention. To control for the possibility of unmeasured differential impact of the intervention on physician specialty, experimental group status was included as a covariate in the expanded model. Second, physicians who had agreed to participate in the original study could have been different from those who declined. External validity is a common challenge in studies that demand time commitments from participating physicians, as was true for this study, and the volunteer rate was low $(16 \%)$. However, the participation rate was about the same for both FP and IM physicians, and any selection bias should be equivalent in both groups. Third, these 
data are derived from encounters with a small sample of female and minority group clinicians. Consequently, physician gender and ethnicity could not reliably be used in analyses. Because of the small number of physicians in this analysis, only one physician variable (age) was included in expanded models. Fourth, because these data were collected in 1995 , it is important to note that communication patterns described above may have shifted during the interim.

\section{Conclusions}

Since the specialty of FP was first recognized, in 1969, differences between the 2 fields have diminished in certain respects. Overall, because of the success of FP clinicians and tremendous shifts in health care systems, case-mix differentials have narrowed and will probably continue to diminish. ${ }^{12,23,39-41}$ However, Family Practice and general Internal Medicine remain distinct specialties with their own philosophies and curricula. ${ }^{42}$ These data exhibit significant differences in the way IM and $\mathrm{FP}$ physicians communicate and provide the first evidence from encounters with board-certified or -eligible physicians describing the role of specialty in communication patterns and corroborate prior research done with resident physicians. We do not know whether the communication differences evident here were caused by training and curricular emphasis of the specialties or the selfselection of physicians to specialties that are consistent with particular interests and style preferences. Certainly, patient self-selection may also play a role in explaining the specialty differences in predictors of patient satisfaction. Further studies are required to evaluate the health impact of these communication differences and to explore the interaction between specialty and patient and physician identity characteristics, such as ethnicity and gender.

Table 6. Categories of Roter Interaction Analysis System (RIAS)

\begin{tabular}{|c|c|c|}
\hline Functional Grouping & Communication Behavior & Example \\
\hline Data-gathering skills & $\begin{array}{l}\text { Question (open ended) medical condition, } \\
\text { therapeutic regimen, lifestyle and self- } \\
\text { care, psychosocial topics } \\
\text { Question (closed ended) medical } \\
\text { condition, therapeutic regimen, lifestyle } \\
\text { and self-care, psychosocial topics }\end{array}$ & $\begin{array}{l}\text { What can you tell me about the pain? } \\
\text { How are meds working? } \\
\text { What are you doing to keep yourself healthy? } \\
\text { What's happening with his father? } \\
\text { Does it hurt now? } \\
\text { Do you take your meds? } \\
\text { Are you still smoking? } \\
\text { Is your wife back? }\end{array}$ \\
\hline $\begin{array}{l}\text { Patient education and counseling } \\
\text { skills }\end{array}$ & $\begin{array}{l}\text { Biomedical information about medical } \\
\text { condition, therapeutic regimen, } \\
\text { biomedical counseling } \\
\text { Lifestyle and self-care information } \\
\text { Psychosocial exchange about problems of } \\
\text { daily living, issues about social } \\
\text { relations, feelings, emotions }\end{array}$ & $\begin{array}{l}\text { The medication may make you drowsy. } \\
\text { I'm prescribing an antibiotic for the infection. } \\
\text { It's very important for you to take the antibiotic } \\
\text { every day and take it all. } \\
\text { Getting plenty of exercise is always a good idea. } \\
\text { I can give you some tips on quitting. } \\
\text { It's important to get out and do something } \\
\text { daily. } \\
\text { The community center is good for company. }\end{array}$ \\
\hline Relationship skills & $\begin{array}{l}\text { Positive talk (agreements, jokes, } \\
\text { approvals, laughter) } \\
\text { Negative talk (disagreements, disapproval, } \\
\text { criticisms, corrections) } \\
\text { Social talk (nonmedical, chit-chat) } \\
\text { Emotional talk, concerns, reassurance, } \\
\text { empathy, partnership legitimation }\end{array}$ & $\begin{array}{l}\text { You look fantastic. } \\
\text { You're doing great. } \\
\text { I think you are wrong, you weren't being } \\
\text { careful. No, I wouldn't want that. } \\
\text { How about those Red Sox last night? } \\
\text { I'm worried about your leg. } \\
\text { I'm sure it will get better. } \\
\text { It sounds like you are angry about it. } \\
\text { We'll get through this together. } \\
\text { Anyone going through this would feel that way. }\end{array}$ \\
\hline Partnering skills & $\begin{array}{l}\text { Facilitation: asking for patient opinion, } \\
\text { asking for understanding, paraphrase } \\
\text { and interpretation, back-channel }\end{array}$ & $\begin{array}{l}\text { What do you think it is? } \\
\text { Do you follow me? } \\
\text { I heard you say you didn't like that. } \\
\text { Let me make sure I've got it right.... } \\
\text { Uh-huh, right, go on, hmm. } \\
\text { I'd like to do a physical now and talk later. } \\
\text { Get up on the table. } \\
\text { Now we'll check your back. }\end{array}$ \\
\hline
\end{tabular}




\section{References}

1. Komaroff AL. Variability in medical practice: an investigative opportunity for general medicine. J Gen Intern Med 1986;1(4 Suppl):S31-4.

2. Bertakis KD, Helms LJ, Azari R, Callahan EJ, Robbins JA, Miller J. Differences between family physicians' and general internists' medical charges. Med Care 1999;37:78-82.

3. Keenan JM, Boling PE, Schwartzberg JG, et al. A national survey of the home visiting practice and attitudes of family physicians and internists. Arch Intern Med 1992;152:2025-32.

4. Franks P, Dickinson JC. Comparisons of family physicians and internists. Process and outcome in adult patients at a community hospital. Med Care 1986; 24:941-8.

5. Garg ML, Mulligan JL, Gliebe WA, Parekh RR. Physician specialty, quality and cost of inpatient care. Soc Sci Med 1979;13C:187-90.

6. Bertakis KD, Callahan EJ, Helms LJ, Azari R, Robbins JA, Miller J. Physician practice styles and patient outcomes: differences between family practice and general internal medicine. Med Care 1998;36: 879-91.

7. Bertakis KD, Robbins JA. Utilization of hospital services. A comparison of internal medicine and family practice. J Fam Pract 1989;28:91-6.

8. Bertakis KD, Robbins JA. Gatekeeping in primary care: a comparison of internal medicine and family practice. J Fam Pract 1987;24:305-9.

9. Robbins JA, Bertakis KD, Rose SD. Costs of care provided by trainees in internal medicine and family practice. West J Med 1983;138:118-9.

10. Cherkin DC, Hart LG, Rosenblatt RA. Patient satisfaction with family physicians and general internists: is there a difference? J Fam Pract 1988; 26:543-51.

11. Cherkin DC, Rosenblatt RA, Hart LG, Schneeweiss $\mathrm{R}$, LoGerfo J. The use of medical resources by residency-trained family physicians and general internists. Is there a difference? Med Care 1987; 25:455-69.

12. Conry CM, Pace WD, Main DS. Practice style differences between family physicians and internists. J Am Board Fam Pract 1991;4:399-406.

13. Smith DH, McWhinney IR. Comparison of the diagnostic methods of family physicians and internists. J Med Educ 1975;50:264-70.

14. Scherger JE, Gordon MJ, Phillips TJ, LoGerfo JP. Comparison of diagnostic methods of family practice and internal medicine residents. J Fam Pract 1980; 10:95-101.

15. Greenfield S, Nelson EC, Zubkoff M, et al. Variations in resource utilization among medical specialties and systems of care. Results from the medical outcomes study. JAMA 1992;267:1624-30.

16. Fiscella K, Franks P, Zwanziger J, Mooney C,
Sorbero M, Williams GC. Risk aversion and costs: a comparison of family physicians and general internists. J Fam Pract 2000;49:12-7.

17. Julnes TE, Baker TA. Family practice and internal medicine office fees: an analysis of charge differences. J Fam Pract 1993;37:35-43.

18. Bennett MD, Applegate WB, Chilton LA, Skipper BJ, White RE. Comparison of family medicine and internal medicine: charges for continuing ambulatory care. Med Care 1983;21:830-9.

19. Nichols GA, Brown JB. Following depression in primary care: do family practice physicians ask about depression at different rates than internal medicine physicians? Arch Fam Med 2000;9:478-82.

20. Adamson TE, Rodnick JE, Guillion DS. Family physicians and general internists: do they treat hypertensive patients differently? J Fam Pract 1989;29: 93-9.

21. MacDowell NM, Black DM. Inpatient resource use: a comparison of family medicine and internal medicine physicians. J Fam Pract 1992;34:306-12.

22. Scherger JE. Priorities in family medicine residency education. Fam Med 1987;19:177-8.

23. Saultz JW. Reflections on internal medicine and family medicine. Ann Intern Med 1996;124:600-3.

24. Carmichael LP. A different way of doctoring. Fam Med 1985;17:4.

25. Gaufberg EH, Joseph RC, Pels RJ, Wyshak G, Wieman D, Nadelson CC. Psychosocial training in U.S. internal medicine and family practice residency programs. Acad Med 2001;76:738-42.

26. Bertakis KD, Robbins JA, Callahan EJ, Helms LJ, Azari R. Physician practice style patterns with established patients: determinants and differences between family practice and general internal medicine residents. Fam Med 1999;31:187-94.

27. Bertakis KD, Azari R, Callahan EJ, Robbins JA, Helms LJ. Comparison of primary care resident physicians' practice styles during initial and return patient visits. J Gen Intern Med 1999;14:495-8.

28. Roter D. The enduring and evolving nature of the patient-physician relationship. Patient Educ Couns 2000;39:5-15.

29. Roter DL, Stewart M, Putnam SM, Lipkin M, Stiles $W$, Inui TS. Communication patterns of primary care physicians. JAMA 1997;277:350-6.

30. Roter DL, Hall JA, Kern DE, Barker LR, Cole KA, Roca RP. Improving physicians' interviewing skills and reducing patients' emotional distress. A randomized clinical trial. Arch Intern Med 1995;155: 1877-84.

31. Ormel J, Koeter MW, van den Brink W, Giel R. Concurrent validity of GHQ-28 and PSE as measures of change. Psychol Med 1989;19:1007-13.

32. Roter D, Frankel R. Quantitative and qualitative approaches to the evaluation of the medical dialogue. Soc Sci Med 1992;34:1097-103. 
33. Roter D, Hall J. The influence of patient characteristics on communication between the doctor and the patient. In: Roter D, Hall J, editors. Doctors talking with patients, patients talking with doctors: improving communication in medical visits. Westport (CT): Auburn House; 1993. p. 39-58.

34. Roter DL, Larson S, Fischer GS, Arnold RM, Tulsky JA. Experts practice what they preach: a descriptive study of best and normative practices in end-of-life discussions. Arch Intern Med 2000; 160:3477-85.

35. Mead N, Bower P. Measuring patient-centredness: a comparison of three observation-based instruments. Patient Educ Couns 2000;39:71-80.

36. Lipsitz SR, Fitzmaurice GM, Orav EJ, Laird NM. Performance of generalized estimating equations in practical situations. Biometrics 1994;50:270-8.

37. Collins KS, Hughes DL, Doty MM, Ives BL, Edwards JN, Tenney K. Diverse communities, common concerns: assessing health care quality for minority Americans. Findings from The Common- wealth Fund 2001 Health Care Quality Survey, March 2002.

38. Hall JA, Roter DL, Rand CS. Communication of affect between patient and physician. J Health Soc Behav 1981;22:18-30.

39. Kravitz RL, Greenfield S, Rogers W, et al. Differences in the mix of patients among medical specialties and systems of care. Results from the medical outcomes study. JAMA 1992;267:1617-23.

40. Noren J, Frazier T, Altman I, DeLozier J. Ambulatory medical care: a comparison of internists and family-general practitioners. N Engl J Med 1980; 302:11-6.

41. Cherkin DC, Rosenblatt RA, Hart LG, Schleiter MK. A comparison of the patients and practices of recent graduates of family practice and general internal medicine residency programs. Med Care 1986;24:1136-50.

42. Stephens GG. Family medicine as counterculture. 1979. Fam Med 1998;30:629-36. 